\title{
Effectiveness of Students Independence Instruments Learning Cake Products and Indonesian Cake
}

\author{
Latifahtur Rahmah1,a*, Luthfiyah Nurlaela 1,b , Agus Budi Santosa2,c \\ ${ }^{1}$ Technology and Vocational Education, Postgraduate Program of Universitas Negeri Surabaya, Surabaya, Indonesia \\ 2 Department of Electronic Engineering, Faculty of Engineering, Universitas Negeri Surabaya, Surabaya, Indonesia \\ a latifahtur.17070895006@mhs.unesa.ac.id; bluthfiyahnurlaela@unesa.ac.id; c agusbudi@unesa.ac.id \\ *Corresponding Author \\ Whatsapp number: [08969967174]
}

How to Cite : Rahmah, L., Nurlaela, L., Santosa, A., B. (2019). Effectiveness of Student Independence Instruments Learning Cake Products and Indonesian Cake. International Journal for Educational and Vocational Studies, 1 (6), 573-577

\section{ARTICLE HISTORY}

Received: 16 June 2019

Revised: 23 July 2019

Accepted: 10 September 2019

\section{KEYWORDS}

Learning Independence;

Indonesian Cake;

and Cake Product;

\begin{abstract}
Independence is a needed skill in the $21^{\text {st }}$ Century. Learning independence will form a habit that will improve work skills. The focus of this research is to see the effectiveness of student independence instruments in learning cake products and Indonesian cake. The approach of this study is a qualitative approach with the trial subjects in this study involving 32 students of class XI Culinary 1 who were teaching cake products and Indonesian cake lessons at SMKN 8 Surabaya. The method used in this study is development research with a 4D model. The results of the validation of the instruments of the students' independence in the decoration material were on average material aspects of 4.36 . The construction was 4.51 , language or culture as well as 4.44 . The assessment of the three validators of the students' independence instruments obtained the results of an average validation of 4.44 in the valid category. The result shows that the instrument was developed accordingly and can use as an instrument of student independence in Indonesian cake and cake product lessons. The reliability of the kappa coefficient for the three observers is $0.548>0.349$. Based on the analysis carried out, it can conclude that the instrument tests the independence of independence and can use as an independent instrument for Indonesian cake and cake product lessons.
\end{abstract}

This is an open access article under the CC-BY-SA license.

\section{INTRODUCTION}

The Directorate of Vocational Education, which was quizzed by Hadam (2017) describes the definition of Vocational High School contained in Article 15 of the National Education System Law of 2003 which states that: Vocational school is secondary education that prepares students primarily to work in certain fields. Vocational education has the general goal of increasing the faith and piety of students to the Almighty God and developing the potential of students to have noble character, noble knowledge, and insight into nationalism; and has a specific purpose, namely to prepare students with knowledge, competence, technology and art to become productive human beings, as well as work independently, fill job vacancies in the business world and industry as middle-level workforce in accordance with the competencies in their respective majors. In this statement, it was explained that the need for independent learning in carrying out work.
In the learning process, the teacher is appointed as the key to the role of being a facilitator to guide students. This opinion is reinforced by the opinion of Suprihatiningrum (2017) that in the learning process, the teacher as the main actor as a facilitator and source manager for students to learn. Learning that adheres to the teacher as a facilitator and not as the main source for obtaining information is very much in line with the views of the 2013 curriculum. The role of the teacher as a facilitator gives students the opportunity to independently find knowledge, knowledge that is found and done independently by students. can be applied easily.

Cake products and Indonesian cake are one of the subjects in the Vocational School majoring in Catering which requires independence. Indonesian Cake and Cake products are subjects of C3 cooking skills competency in the types of competency competencies rather than $\mathrm{C} 1$ basic skills programs. Basic competency Cake decoration is a technique in applying artistic creativity in decorating 
cakes.Cake products and Indonesian cakediscuss in depth about cakes in the form of international snacks and cakes which are snacks from Indonesia. The material starts with making the cake next to the cake to creatively design and decorate a cake. In this last material, students are trained to do work in a mandatory manner. Students are given the freedom to design cake independently and realize what they have designed.

Trilling and Fadel (2009) explain that in the work world there is always a lot of work and boring with the very limited motivation of workers. Workers must come with high motivation must be ready to use their initiative to get things done, and prepare independently in completing their daily work. Teachers must help students become more independent and can use self-service technology tools ranging from the investigation, planning to create projects.

Ilahi (2012) explains that the growth of independence will create a life order that is in harmony with the vision and mission of an educational institution that has a commitment to guide students to be ready to build the future without relying on the help of others. Factually, in vocational high schools do have a commitment to make them skilled independently in accordance with their respective vocational.

The independence of learning in vocational schools has not been done much, the students still assume that the teacher is the only source of knowledge this causes students to become less independent because they only rely on the teacher. Gill and Halim (2007) explain that fostering culture and learning independence habits have become key words of education, especially by changing the learning paradigm and skills desired by the global knowledge economy.

Independence skill is a learning process that uses students as seekers and provides information, in this case, students will be given the obligation to seek knowledge and practice the knowledge without the help of the teacher. Yamin (2008) asserts that independent learning is learning carried out by students freely starting from determining learning goals, learning directions, planning learning processes, learning strategies, learning resources, to making decisions and carrying out activities to achieve the students' learning goals.

Trilling and Fadel (2009) describe that in making an independence instrument there are indicators of independence which are used as guidelines, namely: 1) Managing Goals (goals), namely independence in managing goals and time is realized through (a) setting goals with real and not successful criteria seen; (b) adjusting tactical goals (short term) and strategic (long term); and (c) utilizing time by managing workload efficiently; 2) Independent learning (study), namely independence in learning independently is realized by (a) more than just mastering basic curriculum skills to explore and expand learning; (b) take the initiative to demonstrate lessons for advancing skill levels to the professional level; (c) show commitment to learning as a lifelong process, (d) reflect critically on the experience of past problems for additional material information on experiences of future problems; 3) work independently (work), namely independence in working independently is realized: (1) monitoring tasks; (2) determine assignments; (3) prioritizing tasks and; (4) complete tasks without direct supervision.

Rusman (2016) describes the level of learning independence indicators classified as follows: (1) sterility in Determining Learning Objectives to be achieved means the greater the opportunity is given to students to determine their learning goals, means the greater the chance students learn according to their needs study. Thus, the greater the chance of students to be independent; (2) Independence in Learning in the form of Students can determine learning materials or media that will be used in learning. If students can determine the learning materials, learning media, and ways of learning that will be used to achieve that goal, meaning students have been given the opportunity to be independent; (3) Independence in Learning Outcomes Evaluation shows students can determine the method and criteria for evaluating learning outcomes. At this stage, students can also practice, research and maintain tools, work scope independently.

Trilling and Fadel (2009) describe that indicators of learning independence are students must be able to; (1) managing Goals (goals) Independence in managing goals and time is realized through: (1) setting goals with tangible and invisible success criteria; namely by adjusting tactical goals (short term) and strategic (long term); and take advantage of time by managing workload efficiently; (2) Mandiri study (study); (Independence in learning independently is realized by more than just mastering basic curriculum skills to explore and broaden learning, take the initiative to demonstrate lessons to advance skill levels to the professional level, demonstrate commitment to learning as a lifelong process, reflect critically on experiences of past problems for material additional information on experience of future problems; (3) Working independently (work) Independence in working independently is realized by monitoring tasks, assigning tasks, prioritizing tasks and,

In some vocational high schools, independence instruments are very rarely used. The teacher only focuses on the instruments of cognitive, affective and psychomotor learning outcomes. Most teachers have many obstacles in developing student skills instruments. Based on this, the purpose of this study is to measure effectiveness.

In this study the formulation of the problem which will then be examined includes: (1) how the validity of authentic affective assessment instruments developed based on expert validation ?; (2) how is the reliability of authentic affective assessment instruments developed based on the results of the trial ?; (2) how is the practicality of authentic affective assessment instruments developed based on the results of the trial?. 


\section{METHODS}

This research is development research that refers to the 4D development model. Thiagarajan at al (1974) describes the $4 \mathrm{D}$ development model consisting of 4 main stages, namely: Define, Design, Develop and Disseminate.

The trial subjects in this study were two expert lecturers, and one expert teacher in the field of automotive engineering. In addition, this research also involved 32 XI Class 1 students who were teaching Cake products and Indonesian cake at Surabaya Vocational High School 8. Data obtained in this study, namely: instrument validation data from experts, reliability data, and practicality data instruments based on the results of the trial. The data obtained were analyzed to determine the level of validity, reliability, and practicality of the authentic effective assessment instrument being developed.

\section{RESULTS AND DISCUSSIONS}

\subsection{Define Stage}

The defining stage is determining and defining the needs in the learning process and collecting various information relating to the instrument to be developed starting from: (1) the initial analysis in the form of learning problems; (2) the analysis of students in the form of the initial ability of students of SMKN 8 Surabaya; (3) analysis of tasks in the form of basic competency analysis of Indonesian cakes and cakes; (4) concept analysis in the form of selection of cake decoration material; (5) objective analysis in the form of independence instrument grid.

The instrument in this study is observation, namely the technique of collecting data by observing directly or indirectly about the things observed and taking notes on the observation tool (Sanjaya, 2013).

The material used in this study is the basic competency of cake decoration. While the questionnaire in this study used a Likert scale with five answer choices according to Purwanto (2010), namely: SS (Strongly Agree), S (Agree), KS (Less Agree), TS (Disagree), and STS (Strongly Disagree). This questionnaire is used to find out students who have high independence and students who have low learning independence.

The questionnaire is used to collect information about students' learning independence towards Indonesian cake and cake product subjects on basic cake decorating competencies by giving a checklist $(\sqrt{ })$ to the columns and rows available for each question presented. The instrument of learning independence was developed into 20 questions. The independence grid can be seen in Table 1.

Table 1. Characteristics of student independence in cake decoration material

\begin{tabular}{llc}
\hline \multicolumn{1}{c}{ Indicator } & \multicolumn{1}{c}{ Rated aspect } & Item Number \\
\hline Choose Goals & $\begin{array}{l}\text { Have motivation in learning cake } \\
\text { decorations }\end{array}$ & 1,2 \\
\hline & $\begin{array}{l}\text { Have a purpose in learning cake } \\
\text { decoration }\end{array}$ & 3,4 \\
\hline
\end{tabular}

\begin{tabular}{llc}
\hline \multicolumn{1}{c}{ Indicator } & \multicolumn{1}{c}{ Rated aspect } & Item Number \\
\hline & $\begin{array}{l}\text { Make a learning schedule for learning } \\
\text { cake decorations }\end{array}$ & 5 \\
\hline $\begin{array}{l}\text { Learning } \\
\text { independence }\end{array}$ & $\begin{array}{l}\text { Independent learning of cake } \\
\text { decoration material }\end{array}$ & 6,7 \\
\hline & $\begin{array}{l}\text { Explore cake decorating material } \\
\text { independently }\end{array}$ & $8,9,10$ \\
\hline & $\begin{array}{l}\text { Independence in evaluating learning } \\
\text { cake decorating independently }\end{array}$ & 11,12 \\
\hline Work & $\begin{array}{l}\text { Working on cake decorating work } \\
\text { independently }\end{array}$ & 13,14 \\
\hline & $\begin{array}{l}\text { Prioritize and complete the cake } \\
\text { decorating work independently }\end{array}$ & 15,16 \\
\hline & $\begin{array}{l}\text { Caring for work tools for decorating } \\
\text { cake independently }\end{array}$ \\
\hline & $\begin{array}{l}\text { Caring for the work area of the cake } \\
\text { decoration practice independently }\end{array}$ & 17,18 \\
\hline & \\
\hline
\end{tabular}

\subsection{Design Stage}

The design phase which starts from arranging the test sentence by dividing the positive and negative questions produces 20 items with the answer choices with a score of 1 to 5 .

\subsection{Development Stage}

The develop phase aims to produce instruments of independence for Indonesian cake and cake product lessons that are feasible to use by performing instrument validation and reliability.

\section{Instrument Validation}

Determination of validity is intended to determine the extent to which the accuracy and accuracy of a measuring instrument in carrying out its functions. Beaumont (2009) explains the purpose of validity is to minimize the effort needed to repeat the experiment.

After making the instrument, the validity test will be continued to the experts. Validity test is done to measure the level of accuracy and accuracy of the instruments developed in carrying out its functions. In addition, validity tests are also conducted to test the feasibility of the instrument when it is later used in the learning process.

The scoring system used is: (1) by giving a score of 5 if the quality is very good, easy to understand, very suitable for indicators; (2) score 4 if the quality is good, easy to understand, according to indicators; (3) a score of three 3 if the quality is sufficient, easy to understand, needs to be adjusted to the indicator; (4) score 2 if quality is not good, difficult to understand, need to be adjusted to indicators; and (5) score 1 if the quality is not very good, difficult to understand, not in accordance with the indicators (Purwanto, 2010).

To be clearer, the results of the expert validity test can be seen in Table 2 . 
Table 2. Results of Validation of Student Independence Instruments in cake decoration material

\begin{tabular}{llll}
\hline No & Aspect & Average Value & Category \\
\hline $\begin{array}{l}\text { Material } \\
\text { Language or Culture }\end{array}$ & 4,36 & Valid \\
\hline Construction & 4,51 & Very Valid \\
\hline Language or Culture & 4,44 & Valid \\
\hline Mean Total & 4,44 & Valid \\
\hline
\end{tabular}

As shown in Table 2, the validity test of this authentic effective assessment instrument is divided into 3 parts, including (1) material; (2) construction; (3) language or culture.

Based on the results of the validity test on the material aspects of the students' independence instruments in the decoration material, the results of the average evaluation were 4.36 in the valid category. These results indicate that in terms of the material the instrument developed was in accordance with the indicator material.

In the construction aspects of the student's independence instrument in the decoration material, the average validation results are 4.51 with a very valid category. The construction referred to in this validity test are some of them such: (1) statements in the instrument are formulated briefly and clearly; (2) the sentence in the instrument is free from irrelevant statements, is negative, refers to the past, and (3) the sentence in the instrument is free of uncertain statements.

On the aspect of language or culture, the instrument of student independence in the decoration material obtained the results of the average validation of 4.44 in the valid category. These results indicate that authentic affective assessment instruments have fulfilled language or cultural usage requirements: (1) communicative language; (2) using standard Indonesian; and (3) do not use language that is taboo.

Based on the results of the student's independence instrument validation on decorating material on average on 3 material aspects, construction, language or cultural assessment of the three validators of the students' independence instruments on the decoration material the results of the average validation were 4.44 with valid categories. This shows that the instruments developed are appropriate and can be used as a tool to assess learning independence.

\section{Instrument Reliability}

Reliability is the stability of the score obtained by the same person when tested again with the same test in different situations or from one measurement to another. Reliability can also be interpreted as consistency or consistency. An evaluation instrument is said to have a high-reliability value if the test made has consistent results in measuring what it wants to measure. Reliability provides the consistency that makes the fulfillment of the main requirements, namely the validity of an instrument score results. (Sugiyono, 2013)

At this stage the independence instrument is implemented or tested in real situations, namely in class
XI Catering 1 at SMKN 8 Surabaya. Implementation in class involves teachers, 3 observers, and 32 students. This stage is done to test the level of reliability of the instrument. Reliability, The non-test instruments for affective learning outcomes, psychomotor learning outcomes and independence questionnaire instruments, were carried out by 3 observers to look for similarities and weaving the observer's equation until the observer's perception of equality was reached, to determine tolerance for differences in observations. Kappa Coefficient formula. Cohen-Kappa Reliability

$\mathrm{K}=\frac{\mathrm{P}_{0}-\mathrm{P}_{\mathrm{C}}}{1-\mathrm{P}_{\mathrm{C}}} \quad($ Basuki, 2015: 110)

Information:

$\mathrm{K}=$ Observation coefficient

$\mathrm{P0}=$ Proportion frequency of agreement

$\mathrm{Pc}=$ Opportunity for compatibility between observers

The instrument has agreement criteria if the IKK score is > substantial (0.6) according to the criteria of the kappa agreement.

After the data is obtained, the data is analyzed by mastery classification with the classification of master and non master students adjusted to observer 1, 2 and 3 . Followed by creating a work matrix to calculate the kappa coefficient. After that, analyze the number of non master masters.

Analyzing the number of masters and non-masters from observer 1 and observer 3 is shown in Table 3 .

Table 3. Analyzing the number of masters and non-masters from observer 1 and observer 2.

\begin{tabular}{l|l|l|l|l}
\hline \multicolumn{5}{c}{ Observer 1 } \\
\hline Observer 3 & & Master & Non-Master & \\
\cline { 2 - 5 } & Master & $a=12$ & $b=4$ & $a+b=16$ \\
\cline { 2 - 5 } & $\begin{array}{l}\text { Non- } \\
\text { Master }\end{array}$ & $c=5$ & $d=11$ & $c+d=16$ \\
\cline { 2 - 5 } & & $a+c=17$ & $b+d=15$ & Total 32 \\
\hline
\end{tabular}

Table 4. Analyzing the number of masters and non-masters from observer 1 and observer 3

\begin{tabular}{l|l|l|l|l}
\hline \multicolumn{5}{c}{ Observer 1 } \\
\hline Observer 3 & & Master & Non-Master & \\
\cline { 2 - 5 } & Master & $a=19$ & $b=1$ & $a+b=20$ \\
\cline { 2 - 5 } & $\begin{array}{l}\text { Non- } \\
\text { Master }\end{array}$ & $c=1$ & $d=11$ & $c+d=12$ \\
\cline { 2 - 5 } & & $\begin{array}{l}a+c= \\
20\end{array}$ & $b+d=12$ & Total 32 \\
\hline
\end{tabular}

Table 5. Analyzing the number of masters and non-masters from observer 2 and observer 3

\begin{tabular}{l|l|l|l|l}
\hline \multicolumn{5}{c}{ Observer 1 } \\
\hline Observer 3 & & Master & Non-Master & \\
\cline { 2 - 5 } & Master & $a=15$ & $b=5$ & $a+b=20$ \\
\cline { 2 - 5 } & $\begin{array}{l}\text { Non- } \\
\text { Master }\end{array}$ & $c=1$ & $d=11$ & $c+d=12$ \\
\cline { 2 - 5 } & & $a+c=16$ & $b+d=16$ & Total 32 \\
\hline
\end{tabular}


Information:

a $=$ The number of students classified by the master by the two observers.

$\mathrm{b}=$ Number of students classified as non-masters by observer 1 but classified as master by observer 3 .

$c=$ Number of students classified by master by observer 1 but classified as non master by observer 3 .

$\mathrm{d}=$ Number of students classified as non-masters by both observers.

From the number of masters and non masters from observer 1 and observer 3, analyzed as follows.

P0 by formula:

$\mathrm{P} 0=\frac{(\mathrm{a}+\mathrm{d})}{\mathrm{N}}=\frac{12+13}{32}=\frac{25}{32}=0,781$

Cohen-Kappa Reliability

$\mathrm{KK}=\frac{\mathrm{P} 0-\mathrm{Pe}}{1-\mathrm{Pe}}=\frac{0,781-0,66}{1-0,66}=\frac{0,121}{0,34}=0,345$

From the number of masters and non masters from observer 1 and observer 3, analyzed as follows.

P0 by the formula:

$$
\mathrm{P} 0=\frac{(\mathrm{a}+\mathrm{d})}{\mathrm{N}}=\frac{3+11}{32}=\frac{24}{32}=0,75
$$

Cohen-Kappa Reliability:

$\mathrm{KK}=\frac{\mathrm{P} 0-\mathrm{Pe}}{1-\mathrm{Pe}}=\frac{0,75-0,501}{1-0,501}=\frac{0,514}{0,49}=0,501$

From the number of masters and non masters from observer 2 and observer 3, analyzed as follows.

P0 by formula:

$\mathrm{P} 0=\frac{(\mathrm{a}+\mathrm{d})}{\mathrm{N}}=\frac{15+14}{32}=\frac{29}{32}=0,90$

Cohen-Kappa Reliability

$\mathrm{KK}=\frac{\mathrm{P} 0-\mathrm{Pe}}{1-\mathrm{Pe}}=\frac{0,9-0,5}{1-0,5}=\frac{0,4}{0,5}=0,8$

So it was concluded that the Kappa coefficient for the three observers was as follows.

$\mathrm{Kp}=\frac{0,345+0,501+0,8}{3}=\frac{1,646}{3} \quad 0,548$

Reliability is related to consistency, meaning that whatever is tested, the question has almost the same value. Reliable is also related to Rxy product moment. So that it can be concluded that the question is said to be reliable if it has a calculated proxy $>$ Rxy Tabel. $\mathrm{N}=32$ students and based on the Rxyproduct moment table 0.349 . The reliability of the kappa coefficient for the three observers is $0.548>0.349$. Based on the analysis carried out, it can be concluded that the test instrument is independent independence and can be used as an instrument of independence in learning Indonesian cake and cake product lessons.

\subsection{Disseminate Stage}

After obtaining the results of expert validity and the reliability of the instrument can be used as an instrument to assess the independence of students in Indonesian cake and cake product lessons.

\section{CONCLUSION}

There are 3 core indicators on Indonesian cake and cake product instruments that must be fulfilled, namely independence in choosing goals, independence in learning, and independence in work.

Based on the results of the validation of the student's independence instrument on Indonesian cake and cake products. the average for 3 material aspects is 4.36, construction is 4.51 , language or culture is 4.44 . The assessment of the three validators of the students' independence instruments in the Indonesian cake and cake product lesson resulted in an average validation of 4.44 in the valid category. This shows that the instruments developed are appropriate and can be used as instruments to assess the independence of Indonesian cake and cake product lessons.

The reliability of the kappa coefficient for the three observers is $0.548>0.349$. Based on the analysis carried out, it can be concluded that the instrument tests the independence of independence and can be used as the independence instrument of Indonesian cake and cake product lessons.

\section{REFERENCES}

Basuki dan Hariyanto (2017). Asesmen Pembelajaran. Bandung: PT Remaja Rosdakarya.

Beaumot (2009). Research Methods \& Experimental Design. A set of notes suitable for seminar use.

Gill dan Halim. 2007. Independence Learning. Fremantle: AARE Conference

Ilahi. (2012). Pembelajaran Discovery Strategy and Mental Vocational Skill. Yogyakarta: Diva Press

Purwanto, (2011). Prinsip-Prinsip dan Teknik Evaluasi Pengajaran. Bandung: Rosda Karya.

Sugiyono. (2013). Metode penelitian kuantitatif kualitatif dan R\&D. Bandung: Alfabeta.

Suprihatiningrum. (2017). Strategi Pembelajaran. yogjakarta: Ar- Ruzz Media

Trilling dan Fadel. 2009. 21st Century Skill. San Francisco: Jossey-Bass

Yamin. (2008). Paradigma Pendidikan Konstruktivistik. Jakarta: Gaung Persada Press

Hadam. 2017. Strategi Implementasi Revitalisasi SMK. Jakarta: Direktorat pembinaan SMK:

Sanjaya, Wina. (2013). Penelitian Pendidikan: jenis, metode \& prosedur. Bandung: Kencana Prenada Media Group. 